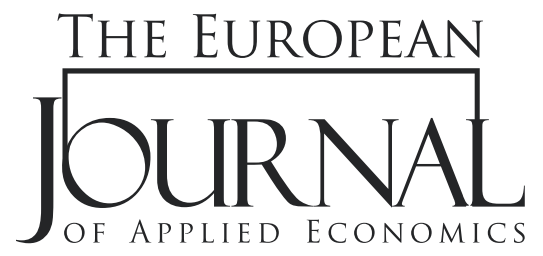

EJAE 2018, 15(1): 110-122

ISSN 2406-2588

UDK: $338.57: 336.763 .2$

330.112.1:316.6

DOI: 10.5937/EJAE15-16665

Original paper/Originalni naučni rad

\title{
BEHAVIORAL ECONOMICS: HOW WELL DO INVESTORS IN SERBIA PREDICT THE STOCK PRICES?
}

\author{
Dora Petronijević \\ PhD candidate, Singidunum University, \\ Belgrade, Serbia
}

\begin{abstract}
:
The main goal of this paper is to investigate whether investors in Serbia can predict future stock prices. This research has been inspired by a number of similar researches conducted in other countries. The research has been conducted on two Belgrade Stock Exchange's indexes: BELEX 15 (represents the market movement of stock prices) and BELEX Sentiment (represents the aggregate investors' predictions of future stock prices behavior). In methodological sense, this analysis was made by using Vector Auto-regression (VAR) model and Granger causality model. The results show that investors in Serbia are not very successful in prediction of future prices. The research also shows that investors have based their expectations on historical prices, which resulted in bad predictions. The results of this research are in cohesion with the previous researches conducted in other developing, transitional countries.
\end{abstract}

\section{Article info:}

Received: February 25, 2018

Correction: March 21, 2018

Accepted: March 28, 2018

\section{Keywords:}

behavioral finance, irrational investor, prediction of stock prices, investor sentiment, market noise

\section{INTRODUCTION}

Most economic models are based on efficient market theory (Fama, 1970), which assumes that all investors are rational. Behavioral studies are pointing out that human irrationalities may cause mistakes and fallacies in economic conclusions and decision making. ${ }^{1}$ The main aim of this paper is to examine the extent to which investors in Serbia can predict the stock prices on Belgrade Stock Exchange. This topic belongs to the field of behavioral economics, as a relatively new scientific research field.

In order to analyze investors' expectations, we will use BELEX Sentiment. BELEX Sentiment represents the aggregate expectations of the investors in Belgrade Stock Exchange regarding future behavior of stock market. It is primarily based on institutional investors' expectations (90\%) (Belgrade Stock Exchange, 2017). Assuming their predictions (expectations) turn out to be generally correct, BELEX Sentiment can be a useful indicator for smaller investors in their decision making.

1 The founders of behavioral economics are Daniel Kahneman and Amos Tversky. They have devoted their carrier on analyzing cognitive biases in humans and its implications on economics. (See more: Kahneman, Slovic, Tversky, 1982; Kahneman, Tversky, 1996; Kahneman, 2011)

Some of the other distinguished authors in this field are Richard Thaler and Dan Ariely. They have both, among other things, discussed the quazi rationality of humans. (See: Thaler, 1991; Ariely, 2012; Ariely, 2010) 
The main hypothesis of this paper is that investors are not successfully predicting the stock prices. This hypothesis will be tested using quantitative models, namely Vector Auto-Regression Model and Granger Causality Test.

\section{Contribution}

Most studies conducted in this field are focusing on developed markets. Very few researchers have analyzed undeveloped markets and this research, as the first one conducted on Serbian market, contributes both to theory and practice.

Majority of other studies have focused on consumer confidence indices (noise traders). This research, on the other hand, analyzes the index primarily based on institutional investors' opinions, which should be more rational as based on economic models. Kling and Gao (2008) have conducted similar research on Chinese market (transitional market), and they have come to conclusion that the institutional investors in China are not predicting the future prices well.

The results of this paper could be of interest to all investors, whether institutional (fund managers, etc) or individual.

The paper consists of introduction, three sections and the conclusion. The first section is dedicated to literature review, presenting the most interesting studies and articles in this research field. The second section is devoted to description of methodology used in the research and the third section presents and discusses the results of the research.

\section{LITERATURE REVIEW}

When analyzing the relationship between returns and Investor Sentiment, researchers have come to different conclusions. Some researchers have found that investor sentiment predicts the future behavior of stock prices (some find positive and some negative relation), while others have come to the opposite conclusion.

Brown and Cliff (2004) have found that investor sentiment predicts market returns over the next one to three years.

Schmeling (2009) has conducted the research on 18 industrialized countries and has found that on average investor sentiment negatively forecasts the aggregate stock returns (value stocks, growth stocks, small stocks). In other words, when sentiment is high, the future stock returns tend to be lower and vice versa. Fisher and Statman (2003) have come to the same conclusion in their research, where they have analyzed the relationship between investor sentiment (for which they have used consumer confidence) and the level of returns of S\&P 500, NASDAQ and small companies' stocks.

Charoenrook (2005) has used University of Michigan Consumer Sentiment Index as a proxy for sentiment of individual investors (High education market). He has found that sentiment is positively related to present excess market returns, and negatively to future market returns. He has analyzed future returns with monthly and yearly horizon.

On the other hand, Lemmon and Portniaguina (2006) have analyzed the relationship between investor sentiment (consumer confidence) and small stock premium, and their research concludes that sentiment doesn't seem to predict future momentum premiums and their value. 
Wang, Keswani and Taylor (2006) have included the lagged returns in their research, and have found that sentiment does not influence the stock returns. Instead, they have discovered that the opposite is true: stock returns influence sentiment. Kling and Gao (2008) have conducted a research on Chinese stock market, and have not found the long-term relationship between investor sentiment and stock prices.

Oprea (2014) has conducted a research on 8 transitional countries. The research has shown that out of 6 analyzed countries sentiment does not Granger cause the future behavior of stock prices, but returns Granger cause sentiment. The exceptions were Lithuania and Hungary, where he has found mutual Granger causality between these two factors.

The results of this research will analyze mutual causality between sentiment and stock returns on Belgrade Stock Exchange. This research will use the same methodology as Oprea (2014), because it is developed for the similar stock market conditions.

\section{RESEARCH SAMPLE AND METHODOLOGY}

In the field of behavioral economics, given the nature of the subject, qualitative analyses are predominant. The space for quantitative research is narrow and it was challenging to find series that allows this kind of analysis. Investor sentiment as instrument is useful because it quantifies aggregate expectations of investors in stock market. This allowed me to make a quantitative research that will analyze the extent to which investors in Serbia can predict the movements of stock prices.

The stock market in Serbia is relatively new and not very developed. After 2000, the trading on secondary market was stimulated because of the privatization of many public companies. Through time some companies got listed on the market and their stocks are continually traded. Until the crisis in 2008, the liquidity of the market and the number of companies continually increased. The idea of mutual regional stock market appeared in this period. Unfortunately, after the crisis the liquidity of the market has dramatically decreased. Even though the market has partially recovered, the liquidity still remains the challenge 'till the present day.

\section{ANALYZED TIME SERIES}

\section{BELEX Sentiment: Its structure and the methodology of its calculation}

BELEX sentiment is calculated as weighted average of three types of market participants. The first group includes the most active members of Stock Exchange that have traded on the market and had an important share of market turnover in the period that preceded the voting. The second group is derived from the portfolio managers in investment and pension funds. The third group is general public (the individuals can vote on the Belgrade Stock Exchange web site). The first and second groups are having equal weighted averages of $45 \%$, and the expectations of general public have the lowest weighted average of $10 \%$. It can be noticed that institutional investors have the biggest influence (90\%) in creation of this sentiment, and they have better knowledge of economics as well as more trading experience than average investor. For that reason one can expect that part of the expectations should be based on economic indicators and market data (the rest is highly influenced by the factors of irrationality). 
The base value of BELEX Sentiment is 100 and it can move in the range between 0 and 200. The values under 100 are representing expectation of prices' decrease and above 100 the expectation of increase. The voters are offered seven potential answers for their expectations: strong, moderate and mild decrease/increase, or stagnation (Belgrade Stock Exchange, 2017).

\section{BELEX 15}

The other series that will be used in the research is BELEX 15. It is used as an indicator of behavior of Serbian financial market. BELEX 15 is a price index of 15 most liquid stocks on Belgrade Stock Exchange. This index was initiated in October 2005 and its base value is 1000 index points (Belgrade Stock Exchange, 2012).

\section{SAMPLE AND METHODOLOGY OF THE RESEARCH}

This research analyzes the mutual causality between BELEX sentiment and BELEX 15 . The data used for this research is issued by Belgrade Stock Exchange, and the analyzed period is between October 2005 and December 2014.

BELEX 15 is issued daily, while BELEX sentiment is issued monthly. For that reason, BELEX 15 had to be converted into monthly time series. This transformation is performed by averaging. The final sample has 111 observations.

In order to find a trend, both time series have been logarithmed. Neither of the two series has seasonal component, which means, that there is not seasonal regularity in yearly movements of series.

The quantitative research, presented in this paper, will include lagged (past) values of both series and will analyze their mutual causality. Therefore, an adequate Vector Autoregressive (VAR) model will be created and through the estimated VAR model we will analyze mutual causality of time series through Granger causality test. Granger causality test analyzes if the past values of one time series can improve the prediction of the behavior of the other series.

In order to crate adequate VAR model it is necessary to perform numerous tests such as: a) Unit root tests: Augmented Dickey Fuller test and Kwiatkowsky-Phillips-Schmidt-Shin (KPSS) test. b) Sequential testing and information criteria will suggest the optimal number of lags for VAR model. c) Box - Ljung autocorrelation test. d) Dornik- Hansen normality test.

\section{RESULTS AND DISCUSSION}

The transformation of time series (they have both been logarithmed), is followed by unit root test of time series. The following graphs are presenting the analyzed series and their first differentials. 
BELEX Sentiment

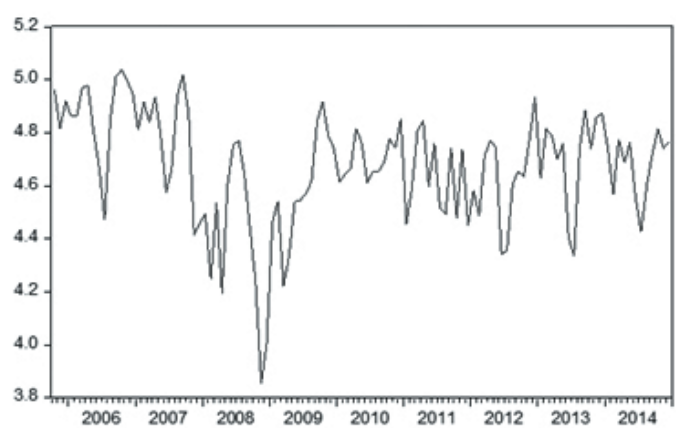

BELEX 15

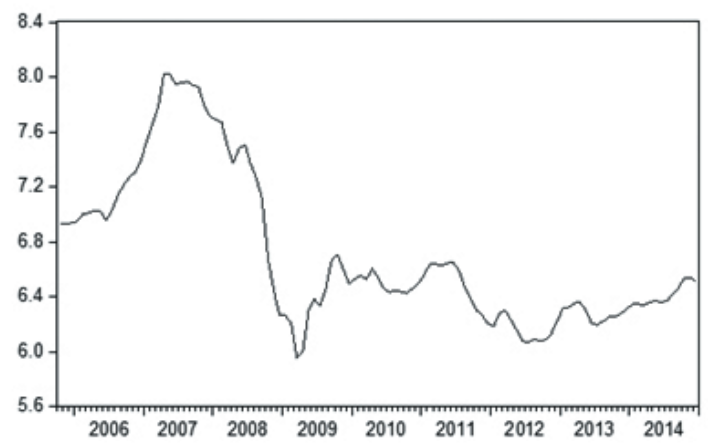

D(BELEX Sentiment)

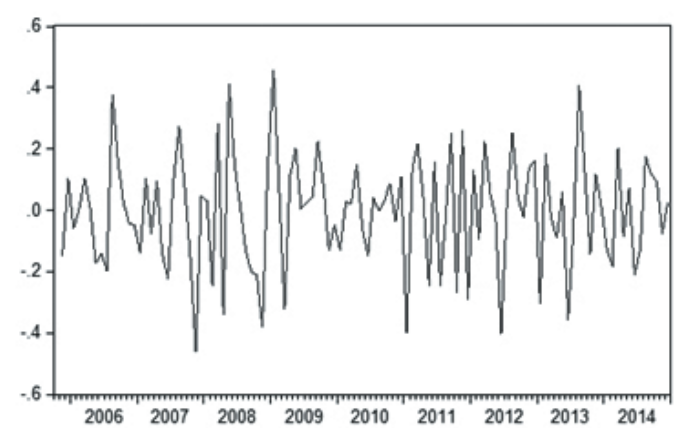

D(BELEX 15)

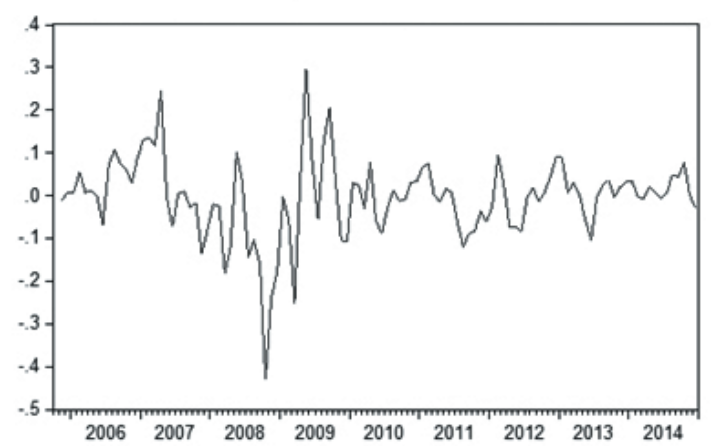

Figure 1. BELEX 15 \& BELEX Sentiment and their first differentials

Source: Graphs are created by author in E-views program

\section{Stationarity of time series - Unit root testing}

Many series in economic researches are non-stationary. The non-stationary time series is a series that has stochastic trend, which means that its behavior cannot be predicted based on historical data (Gujarati \& Porter, 2009). Variance of non-stationary time series is not constant, but time variant. Constant variance is the basic assumption of standard linear regression (Mladenović \& Petrović, 2010). If this assumption is not met, the results gained by model become unreliable. For that reason, if the series turns out to be non-stationary, the researcher has two options: a) if all analyzed time series are non-stationary, but are co-integrated (their behavior is highly synchronized, which makes their linear combination stationary), they do not have to be altered in further analyses. B) if that is not the case, non-stationary series have to be differentiated. (Mills \& Markellos, 2008)

The stationarity of time series is tested in this paper, using the Augmented Dickey Fuller (ADF) and Kwiatkowsky-Phillips-Schmidt-Shin (KPSS) unit root tests. The results of ADF test are presented in the following table: 


\begin{tabular}{|c|c|c|c|c|c|c|c|}
\hline \multirow{2}{*}{$\begin{array}{l}\text { The name } \\
\text { of time } \\
\text { series }\end{array}$} & \multicolumn{3}{|c|}{$\mathrm{H}_{0}: \mathrm{I}(1), \mathrm{H}_{1}: \mathrm{I}(0)$} & \multicolumn{3}{|c|}{$\mathrm{H}_{0}: \mathrm{I}(2), \mathrm{H}_{1}: \mathrm{I}(1)$} & \multirow[b]{2}{*}{$\begin{array}{c}\text { Deterministic } \\
\text { components }\end{array}$} \\
\hline & $\mathrm{ADF}$ & $\begin{array}{c}\text { Critical } \\
\text { value } \\
\text { (5\% level) }\end{array}$ & $\mathrm{N}^{\circ}$ of lags & $\mathrm{ADF}$ & $\begin{array}{c}\text { Critical } \\
\text { value } \\
\text { (5\% level) }\end{array}$ & $\mathrm{N}^{\circ}$ of lags & \\
\hline BELEX 15 & -0.35 & -1.94 & 3 & -3.52 & -1.94 & 2 & None \\
\hline $\begin{array}{l}\text { BELEX } \\
\text { sentiment }\end{array}$ & -5.39 & -2.89 & 0 & - & - & - & Constant \\
\hline
\end{tabular}

Table 1. The results of ADF test

Source: Calculations are performed by author in E-views program

Null hypothesis (H0) of ADF test states that the series is not stationary (has one unit root), the alternative hypothesis (H1) is that the time series is stationary (Dickey \& Fuller, 1979).

The critical values given in the table have been calculated at the significance level of $5 \%$ for the sample size of 111 observations. The levels of critical values vary depending on the deterministic components included in the test. Stock Watson test has been performed in order to determine which deterministic components should be included.

BELEX 15 has higher ADF value than the critical value, which leads to the conclusion that series has at least one unit root. After testing for the presence of two unit roots in the series, it has been concluded that series has only one unit root (ADF value is lower than critical value). BELEX Sentiment on the other hand has lower ADF value than the critical value. This has led to the rejection of the H0, and the acceptance of $\mathrm{H} 1$, that states that this series has no unit roots.

These results will be additionally tested using KPSS unit root test. This test is based on different methodology than ADF test.

\section{KPSS test}

Contrary to ADF test whose $\mathrm{H}_{0}$ assumes that the series is not stationary (has one unit root), the $\mathrm{H}_{0}$ of KPSS test assumes that the series is stationary (Kwiatkowsky et al., 1992). Therefore the $\mathrm{H}_{1}$ of KPSS test is that the series has unit root. Critical value at the significance level of $5 \%$ in this model equals 0.463 for both variables. KPSS statistic for BELEX sentiment is 0.191 , which leads to the conclusion that the series is stationary. KPSS statistic for BELEX 15 equals 0.74 ; leading to the conclusion that BELEX 15 is not stationary time series.

The results of KPSS test have confirmed the results gained by ADF test. BELEX sentiment is stationary series and BELEX 15 has one unit root. The combination of stationary and non-stationary series always produces a non-stationary process (process with unit root). Therefore, we will use the first differential of BELEX 15 in the following research.

\section{Vector Auto-regression model - VAR model}

The time series in this model are represented in matrices - for that reason it has vector in its name. For example, vector time series $\mathrm{X}_{\mathrm{t}}$ with dimensions $\mathrm{m} \times 1$ can be presented as follows: 


$$
X_{t}=\left[\begin{array}{l}
x_{1 t} \\
x_{2 t} \\
\cdots \\
x_{m t}
\end{array}\right], t=1,2, \ldots
$$

The use of vector time series allows us to analyze the dynamic relationship between variables in the model. Each variable is modeled both by its previous values - lags (this explains why the name of the model includes the term auto-regression), as well as the previous values of other variables in the model.

The dimension of VAR model equals to the number of time series included in the model. Therefore the dimension of VAR model in this research is 2, since it includes two time series BELEX Sentiment and differentiated BELEX 15 (d (BELEX15)). Constant is the only deterministic component included in the model (Tsay, 2010).

In order to create adequate VAR model, we have to determine its order (the optimal number of lags included in the model) (Brooks, 2008: 293-295). So, if it is determined that the optimal number of lags in the model equals 2, than we say that that the model is VAR(2) model. It is important that the model is both congruent and economical. Congruent model is in accordance with all sources of information and time sustainable. In other words, it cannot have autocorrelation. Economical model includes only the necessary number of parameters. The use of higher lag order than optimal in VAR model will dramatically increase the number of parameters in the model.

The optimal number of lags in this model was searched using sequential testing and information criteria (Akaike information criterion - AIC (1974), Schwarz information criterion - SC (1978) and Hannan-Quinn information criterion - HQ (1979)). The results are presented in the table below:

\begin{tabular}{lcccccc}
\hline Lag & LogL & LR & FPE & AIC & SC & HQ \\
\hline 0 & 128.2693 & NA & 0.000316 & -2.38244 & -2.33219 & -2.362072 \\
\hline 1 & 177.5828 & 95.83559 & 0.000135 & -3.23741 & -3.08665 & -3.176307 \\
\hline 2 & 179.7577 & 4.144642 & 0.000139 & -3.20298 & -2.95171 & -3.101135 \\
\hline 3 & 189.5877 & 18.36174 & 0.000125 & -3.31298 & -2.96120 & -3.170399 \\
\hline 4 & 190.1939 & 1.109354 & 0.000133 & -3.24894 & -2.79666 & -3.065628 \\
\hline
\end{tabular}

Table 2. Identification of the optimal VAR model lag

Source: Calculations are performed by author in E-views program

Sequential testing and AIC suggest that the optimal lag order for the VAR model is 3 while SC and HQ are suggesting that the lag order of the model should be 1. VAR (1) model has autocorrelation, and is therefore not adequate.

If residuals of suggested VAR (3) model prove not to have autocorrelation and if they are normally distributed, this model will be accepted. 


\section{Autocorrelation test (Auto- and Cross- correlation)}

In this research, the presence of autocorrelation in residuals is tested by Box-Ljung autocorrelation test.

The null hypothesis of this test is that there is no auto- or cross- correlation in the residual series, the alternative hypothesis is that the residuals are auto- and/or cross-correlated.

\begin{tabular}{lccccccccc}
\hline Lags & 4 & 5 & 6 & 7 & 8 & 9 & 10 & 11 & 12 \\
\hline Adj Q-Stat & 7.36 & 8.01 & 8.46 & 11.95 & 28.70 & 31.71 & 35.85 & 40.01 & 41.51 \\
\hline p value & 0.39 & 0.71 & 0.90 & 0.89 & 0.19 & 0.24 & 0.25 & 0.26 & 0.36 \\
\hline
\end{tabular}

Table 3. Results of multidimensional Box-Ljung autocorrelation test

Source: Calculations are performed by author in E-views program

The results show that in the residual series of estimated VAR (3) model has no auto- or cross- correlation.

\section{Dornik-Hansen normality test}

The null hypothesis is that the residuals of estimated VAR (3) model are multivariate normal and the alternative hypothesis is that they are not normally distributed.

\begin{tabular}{cccc}
\hline Component & Jarque-Bera & Degrees of freedom & $\mathrm{p}$ - value \\
\hline 1 & 19.0198 & 2 & 0.0001 \\
\hline 2 & 4.5119 & 2 & 0.1048 \\
\hline Joint & 23.5317 & 4 & 0.0001 \\
\hline
\end{tabular}

Table 4. Dornik-Hansen normality test

Source: Calculations are performed by author in E-views program

The above data shows that residuals in estimated VAR (3) model are normally distributed.

Since we have found that residuals are both normally distributed and have no auto- or cross- correlation, it can be concluded that the optimal lag order for this VAR model is 3 .

VAR (3) model of the time series analyzed in this research can be presented by following set of equations:

$$
\begin{aligned}
& d\left(L N_{-} B E L E X 15\right)_{t}=\alpha_{0}+\sum_{j=1}^{3} \alpha_{j} d\left(L N_{-} B E L E X 15\right)_{t-j}+\sum_{j=1}^{3} \beta_{j} L N_{-} \text {Sentiment }_{t-j}+u_{1 t} \\
& L N_{-} \text {Sentiment }_{t}=\alpha_{o}+\sum_{j=1}^{3} \alpha_{j} d\left(L N_{-} \text {BELEX15) }\right)_{t-j}+\sum_{j=1}^{3} \beta_{j} L N_{-} \text {Sentiment }_{t-j}+u_{2 t}
\end{aligned}
$$


Where $\alpha_{0}$ represents constant, $\mathrm{j}$ represents the number of lags, $\alpha_{\mathrm{j}}$ and $\beta_{\mathrm{j}}$ are parameters for analyzed time series (d(BELEX15) and Sentiment), and u represents error term.

\section{Granger causality test}

Through the estimated VAR (3) model the mutual interdependence of variables will be tested. The analysis will be made by using Granger causality test (Granger, 1969).

This test is based on the assumption that if one variable $\left(\mathrm{x}_{\mathrm{t}}\right)$ influences the movement of the other one $\left(y_{t}\right)$, then its lags should statistically significantly influence the behavior of $y_{t}$. If the causality is proven, than one can say that time series $x_{t}$ Granger causes $y_{t}$. If it turns out that $x_{t}$ causes $y_{t}$, but not vice versa ( $y_{t}$ doesn't Granger causes $x_{t}$ ), this implies that $x_{t}$ is exogenous time series in reference to $y_{t}$. If none of the series Granger causes the other, than we refer to these series as independent. Finally, if both series Granger cause one another, this implies mutual interdependence of the variables (Brooks, 2008: 298; Mladenović \& Nojković, 2011: 113).

It is important to stress that Granger causality shows correlation between historical values of one variable with present value of the other variable. Granger causality does not necessarily imply that changes in movement of one variable cause the movement of the other (Brooks, 2008: 298).

Granger causality test is conducted on analyzed time series and on the following tables one can see the results

Dependent variable: DBELEX15

\begin{tabular}{|c|c|c|c|}
\hline & $\chi^{2}$ & Degrees of freedom & $\mathrm{p}$ value \\
\hline $\begin{array}{l}\text { BELEX } \\
\text { SENTIMENT }\end{array}$ & 3.561405 & 3 & 0.3129 \\
\hline All & 3.561405 & 3 & 0.3129 \\
\hline \multicolumn{4}{|c|}{ Dependent variable: BELEX_SENTIMENT } \\
\hline & $\chi^{2}$ & Degrees of freedom & $\mathrm{p}$ value \\
\hline BELEX 15 & 34.39383 & 3 & 0.0000 \\
\hline All & 34.39383 & 3 & 0.0000 \\
\hline
\end{tabular}

Table 5. Granger causality test

Source: Calculations are performed by author in E-views program

The results of the test show that in short term BELEX sentiment doesn't Granger cause BELEX 15, on the other hand, BELEX 15 Granger causes BELEX sentiment. These results indicate that investors in Serbia are not very successful in predicting the future behavior of stock prices. On the other hand, the fact that BELEX 15 Granger causes BELEX Sentiment implies that investors in Serbia are basing their expectations on historical movements of BELEX 15, which, based on this data, is obviously not the best predictor of future price movements.

This result is in accordance with Wang, Keswani and Taylor (2006) that have also included the lagged returns in their research, as well as with the results of comparative analysis conducted on the sample of 8 post-socialist countries (Bulgaria, Czech Republic, Estonia, Hungary, Lithuania, Poland, Romania 
and Slovenia). However, as both of the studies above have analyzed consumer confidence indices, one would expect that BELEX Sentiment, which is primarily derived from institutional investors' opinions, would be able to predict better BELEX 15 behavior.

This result can be explained by the fact that securities market in Serbia is relatively new (its true development has started in 2000) and undeveloped. Therefore, investors didn't have the benefit of prolonged empirical exposure in order to further their knowledge and skills. The same problem was observed in China (their market started developing after 1992) (Kling \& Gao, 2008).

The development of the market and the increase of investors' experience should through time lead toward improvement in the quality of market predictions. Investors should also be aware of the cognitive biases (irrationalities) that are characteristic for all humans, and that can influence the wrong decision making.

In decision making, human brain uses heuristics that allow us to efficiently process the data and make adequate decisions (Kahneman, Slovic \& Tversky, 1982). This useful characteristic of human brain has inherent risk of ignoring potentially important data, which can sometimes lead to lower quality, less reliable and even flawed decisions.

Some of the typical human mistakes that influence the decision making in investing are: Humans don't pay enough attention to size and representativeness of sample. Number of authors is pointing out that individuals often overestimate their capabilities and are overly confident in their beliefs and forecasts (Bodie, Kane, Marcus, 2009: 260). Ariely (2010) has also pointed out that individuals are often overly confident in the investment strategies that have worked well in the past and keep using them even when the market circumstances dramatically change. Researchers have further found that humans are often unwilling to change their original decision, even when they realize that they have made a mistake (Ariely, 2010: 200-201). They react too slowly on new information on market (conservativism, inertion), which can lead to bad investment decisions, especially in modern, increasingly dynamic world (mistake of keeping status quo).

Kahneman and Tversky (1996) have conducted numerous experiments that have analyzed the problem of unreliability of memory. The experiments have shown that individuals tend to give more importance to the events that happened recently then to the ones that happened further in the past. For example, if a company has recently had good business results, investors are prone to expect the same or even better future profitability.

The awareness that investors (like all humans) are prone to these cognitive biases, should also help them improve their decision making process.

\section{CONCLUSIONS}

Contemporary behavioral economics stresses that human irrationality often has an important influence on decision making, therefore causing significant economic consequences. Consequently, it is essential to take into consideration the impact of human psychology when creating effective risk management strategies. The scientists are trying to develop behavioral risk models and their creation may soon become a reality thanks to big data, development of behavioral and social sciences and human resources management (Lo, 2016).

This research has analyzed how well do investors in Serbia predict the future stock prices. The initial hypothesis that investors on Belgrade Stock Exchange are not good in predicting the future stock returns has been confirmed. The research has further shown that investors are basing their expectations on historical data. 
This result can be explained by the fact that securities market in Serbia is relatively new and undeveloped. Through time and development of the market, investors should keep furthering their knowledge and skills in order to improve the quality of their investments. They should also be mindful of cognitive biases that can influence their decision making.

Further development of securities market in Serbia, together with inclusion of derivatives, will create new space for this kind of research. Consequently, it would be interesting to conduct a similar research that would include spot and futures prices (which naturally incorporate human expectations).

Considering that behavioral economics is predominantly qualitative analytic field, there is also broad scope for qualitative researches, which would complement and enrich previous results. Qualitative research could include various exogenous factors (political system, regulations, customs, culture), as well as endogenous factors which affect decision making process in investment. It is very important to continue with the research relating to cognitive biases (irrational fear of new; unjustified adhering to practices that are no longer profitable in changed circumstances etc.). Further development of both quantitative and qualitative researches in combination with big data could lead to development of new behavioral risk models.

\section{REFERENCES}

Akaike, H. (1974). A New Look at the Statistical Identification Model. IEEE Transactions on Automatic Control, 19(6), 716-723. DOI: 10.1109/TAC.1974.1100705

Ariely, D. (2012). Predictably Irrational: The Hidden Forces That Shape Our Decisions (2 ${ }^{\text {nd }}$ ed.). New York: Harper Collins.

Ariely, D. (2010). The Upside of Irrationality: The Unexpected Benefits of Defying Logic at Work and at Home. New York: Harper Collins.

Belgrade stock exchange. (2017). BELEX Sentiment. Retrieved February 14, 2018, from http://www.belex.rs/files/ trgovanje/BELEXsentiment-objasnjenjekalkulacija.pdf. In Serbian.

Belgrade stock exchange. (2012, August). Metodologija za izračunavanje BELEX 15 indeksa. Retrieved February 14, 2018, from http://www.belex.rs/files/trgovanje/BELEX15_metodologija.pdf. In Serbian.

Bodie, Z., Kane A., \& Marcus A. J. (2009). Osnovi investicija. Belgrade: Data Status. In Serbian.

Brooks, C. (2008). Introductory Econometrics for Finance. Cambridge: Cambridge University Press.

Brown, G. W., \& Cliff, M. T. (2004). Investor Sentiment and the Near-Term Stock Market. Journal of Empirical Finance, 11(1), 1-27. DOI:10.1016/j.jempfin.2002.12.001

Charoenrook, A. (2005, June). Does Sentiment Matter? Retrieved March 31, 2018, from https://apps.olin.wustl. edu/workingpapers/pdf/2008-12-003.pdf

Dickey, D.A., \& Fuller, W. A. (1979). Distribution of the Estimators for Autoregressive Time Series with a Unit Root. Journal of the American Statistical Association, 74(366), 427-431. DOI: 10.1080/01621459.1979.10482531

Fama, E.F. (1970). Efficient Capital Markets: A Review of Theory and Empirical Work. The Journal of Finance, 25(2), 383-417. DOI: $10.2307 / 2325486$

Fisher, K. L., \& Statman, M. (2003). Consumer confidence and stock returns. Journal of Portfolio Management, 30(1), 115-127. DOI: 10.3905/jpm.2003.319925

Granger, C. W. J. (1969). Investigating Causal Relations by Econometric Models and Cross-Spectral Methods. Econometrica, 37(3), 424-438. DOI: 10.2307/1912791

Gujarati, D. N., \& Porter, D. C. (2009). Basic Econometrics. New York: McGraw-Hill.

Hannan, E. J., \& Quinn, B. G. (1979). The Determination of the order of an autoregression. Journal of the Royal Statistical Society, 41(2), 190-195. 
Kahneman, D., Slovic, P., \& Tversky, A. (1982). Judgment under Uncertainty: Heuristics and Biases. New York: Cambridge University Press.

Kahneman, D., \& Tversky, A. (1996). On the Reality of Cognitive Illusions. Psychological review, 103(3), 582-591. DOI: $10.1037 / 0033-295 X .103 .3 .582$

Kahneman, D. (2011). Thinking, Fast and Slow. New York: Farrar, Straus and Giroux.

Kling, G., \& Gao, L. (2008). Chinese Institutional Investor's Sentiment. International Financial Markets, Institutions and Money, 18(4), 374-387. DOI: 10.1016/j.intfin.2007.04.002

Kwiatkowski, D., Phillips, P. C. B., Schmidt, P., \& Shin, Y. (1992). Testing the Null Hypothesis of Stationarity Against the Alternative of a Unit Root. Journal of Econometrics, 54(1-3), 159-178. DOI: 10.1016/03044076(92)90104-Y

Lemmon, M., \& Portniaguina, E. (2006). Consumer confidence and asset prices: some empirical evidence. Review of Financial Studies, 19(4), 1499-1529. DOI: 10.1093/rfs/hhj038

Lo, A. W. (2016). The Gordon Gekko Effect: The Role of Culture in the Financial Industry. FRNBY Economic Policy Review, 22(1), 17-42. DOI: 10.2139/ssrn.2615625

Mills, T., \& Markellos, R.N. (2008). The Econometric Modeling of Financial Time Series. Cambridge: Cambridge University Press.

Mladenović, Z., \& Nojković A. (2011). Analiza vremenskih serija: primeri iz srpske privrede. Beograd: Ekonomski fakultet. In Serbian.

Mladenović, Z., \& Petrović P. (2010). Uvod u ekonometriju. Beograd: Ekonomski fakultet. In Serbian.

Oprea, D. S. (2014). Does Investor Sentiment Matter in Post-Communist East European Stock Markets? International Journal of Academic Research in Business and Social Sciences, 4(8), 356-366. DOI: 10.6007/IJARBSS/ v4-i8/1104

Schmeling, M. (2009). Investor Sentiment and Stock Returns: Some International Evidence. Journal of Empirical Finance, 16(3), 394-408. DOI: 10.1016/j.jempfin.2009.01.002

Schwarz, G. (1978). Estimating the Dimension of a Model. The Annals of Statistics, 6(2), 461-464. DOI: 10.1214/ $\operatorname{aos} / 1176344136$

Thaler, R. (1991). Quazi Rational Economics. New York: Russell Sage Foundation.

Tsay, R. (2010). Analysis of Financial Time Series. New Jersey: John Wiley \& Sons.

Wang Y. H., Keswani, A., \& Taylor, S. J. (2006). The Relationships between Sentiment, Returns and Volatility. International Journal of Forecasting, 22(1), 109-123. DOI: 10.1016/j.ijforecast.2005.04.019 


\section{BIHEVIORALNA EKONOMIJA: KOLIKO DOBRO INVESTITORI U SRBIJI PREDVIĐAJU CENE AKCIJA?}

\section{Rezime:}

Većina ekonomskih modela je bazirana na teoriji efikasnih tržišta koja između ostalog pretpostavlja da su svi investitori racionalni. Bihevioralne studije, sa druge strane, istražuju iracionalne aspekte ljudskog ponašanja i procesa donošenja odluka. Ove studije ukazuju da date iracionalnosti mogu izazvati greške i slabosti u ekonomskom zaključivanju. Cilj ovog rada je da istraži koliko dobro investitori u Srbiji predviđaju buduće cene akcija. Ovo istraživanje je inspirisano sličnim istraživanjima sprovedenim u drugim zemljama. Istraživanje analizira uzajamni odnos dva indeksa Beogradske berze: BELEX 15 (predstavlja tržišno kretanje cena) i BELEX Sentiment (predstavlja agregatno predviđanje investitora o kretanju budućih cena). Sa metodološkog stanovišta, ova analiza je sprovedena korišćenjem Vektorsko Autoregresionog modela (VAR) i Grandžerovog modela kauzalnosti. Rezultati istraživanja ukazuju da investitori u Srbiji nisu veoma uspešni u predviđanju budućih cena. U idealnoj situaciji BELEX Sentiment bi trebalo da može da predvidi kretanje BELEXa 15, međutim ovo istraživanje pokazuje da BELEX15 utiče na kretanje Sentimenta, a ne obrnuto. Iz toga možemo zaključiti da investitori u Srbiji baziraju svoja očekivanja na istorijskom kretanju cena. Rezultati ovog istraživanja su u skladu sa rezultatima sličnih istraživanja sprovedenih u drugim zemljama u razvoju.

\section{Ključne reči:}

bihevioralne finansije, iracionalni investitor, predviđanje cena akcija, investicioni sentiment, tržišni šum 